\title{
Comparative analysis of GSTM1/GSTT1 null alleles and Ile105Val GSTP1 variant in patients with Nasal Polyposis and hyposmia in a Romanian population group
}

\section{Analiza comparativă a polimorfismelor GSTM1/GSTT1 şi Ile105Val GSTP1 la pacienții cu polipoză nazală şi hiposmie într-un grup populațional din România}

\author{
Iuliu Vlad Cătană ${ }^{1}$, Radu Anghel Popp², Victor Pop Ioan², Andreea Cătană²*, \\ Doinel Rădeanu ${ }^{1}$, Alma Maniu ${ }^{1}$, Marcel Cosgarea ${ }^{1}$ \\ 1. “Iuliu Hatieganu” University of Medicine and Pharmacy, Otorhinolaryngology Department, \\ Emergency County Hospital, Cluj-Napoca, Romania \\ 2. "Iuliu Hatieganu" University of Medicine and Pharmacy, Department of Molecular Sciences, Cluj- \\ Napoca, Romania
}

\begin{abstract}
Background. Polymorphisms for genes encoding glutathione S-transferase (GSTM1/GSTT1/GSTP1) might be one of the factors that can influence the variability in susceptibility for hyposmia in normal and ENT pathology associated individuals. The role of GST family enzyme might be important in exposure to xenobiotic induced damage of nasal mucosa. Objectives. To evaluate of distribution of GST variants (GSTM1/GSTT1 null alleles and Ile105Val GSTP1 polymorphism) among patients with hyposmia and normal individuals by using a case-control study. Subjects The study included 75 cases of hyposmic patients (evaluated with "Sniffin' Sticks" olfaction Test), recruited from the Otorhinolaryngology Department of Emergency County Hospital, Cluj-Napoca and 124 healthy unrelated controls. Methods. GSTM1 and GSTT1 variants genotyping was accomplished using a Multiplex PCR method, followed by agarose gel electrophoresis. GSTP1 Ile105Val gene variant was genotyped using PCR-RLFP technique. Results. Comparative analysis for Ile 105Val variant of GSTP1 gene revealed no statistical differences among patients and controls $(\chi 2=3.012, p=0.087, O R=1.514, C I=0.491$ to 1.572$)$. Molecular analysis did not reveal an increased frequency for GSTT1 and GSTM1 null alleles in the patients group compared to controls (GSTT1 - 95\% CI = 0.332 to $1.261, p=$ 0.192, $O R=0.641, \chi^{2}=2.120$, GSTM1 $-95 \% C I=0.171$ to 0.592, $\chi 2=2.017$, OR $=0.321, p=0.062$ ). Significant statistical differences were found when combined GSTM1 and GSTT1 null genotypes (double-null genotypes) were compared between patients and controls $(p=0.0015, O R=4.0351 ; C I=1.706-9.543)$ and when comparing allergic NP patients with non-allergic NP patients ( $p=0.027, O R=3.455, C I=1.147-10.406)$. Conclusions. The presence of both GSTM1/GSTT1 null genotypes (double null genotypes) is considered to be a risk factor for NP and hyposmia development in allergic individuals. The results of our study show no correlation between Ile105Val polymorphism of GSTP1 gene and nasal polyposis associated hyposmia in this Romanian group population.
\end{abstract}

Keywords: GST, Polymorphism, Nasal polyposis, Hyposmia *Corresponding author: Andreea Cătană, "Iuliu Hatieganu” University of Medicine and Pharmacy, Molecular
Science Department, Cluj-Napoca, Romania, Pasteur Str. No.6, E-mail: catanaandreea@gmail.com 


\section{Rezumat}

Introducere. Polimorfisme genelor care codifică glutation S-transferazele (GSTM1/GSTT1/GSTP1) ar putea fi unul dintre factorii care pot influența variabilitatea susceptibilității pentru polipoză nazală şi hiposmie la indivizii sănătoşi sau pacienții cu afecțiuni ORL. Rolul enzimelor din familia GST ar putea fi important în expunerea la leziunile induse de xenobiotice la nivelul mucoasei nazale. Obiective. Evaluarea distribuției variantelor polimorfice GST (alele nule GSTM1/GSTT1 şi polimorfismului Ile105Val GSTP1) în randul pacienţilor cu polipoză nazală şi hiposmie într-un studiu de tip caz-control. Subiecți. Studiul include 75 de cazuri de pacienți cu polipoză nazală şi hiposmie (evaluați cu Testul de olfacție "Sniffin'Sticks"), recrutați din cadrul Departamentului de Otorinolaringologie a Spitalului Județean de Urgenţă, Cluj-Napoca şi 124 controale fără hiposmie şi patologii ORL asociate. Metode. Genotiparea GSTM1 şi GSTT1 a fost realizată folosind metoda Multiplex PCR, urmată de electroforeză în gel de agaroză. Varianta Ile 105Val a genei GSTP1 a fost genotipată cu ajutorul tehnicii PCR-RLFP. Rezultate. Analiza comparativă pentru varianta Ile105Val a genei GSTP1 nu a relevat diferențe statistic semnificative între pacienți şi controale $(\chi 2=3.012, p=0.087$, $O R=1.514, C I=0.491-1.572)$. Analiza moleculară nu a evidențiat o frecvență crescută pentru alele nule GSTT1 şi GSTM1 în grupul de pacienți, comparativ cu controalele. GSTT1, $(95 \%$ CI $=0.332-1.261, p=0.192$, OR $=0.641, \chi 2$ = 2.120), GSTM1, (95\% CI =0.171 - 0.592, $\chi 2=2.017, O R=0.321, p=0.062)$, însă au fost identificate diferențe semnificative între purtătorii ambelor alele nule (heterozigoți dublu-nuli) şi riscul de a dezvolta polipoză nazală comparativ cu lotul de control ( $p=0.0015$, OR=4.0351; $C I=1.706-9.543$. De asemenea s-a evidențiat un risc crescut pentru polipoză nazală şi hiposmie la pacienții alergici comparativ cu cei fără alergii $(p=0.027$, OR=3.455, CI=1.14710.406) Concluzii. Prezența concomitentă a genotipurilor nule GSTM1/GSTT1 (dublu - nule) este considerată un factor de risc pentru dezvoltarea NP şi hiposmiei la persoanele alergice. Rezultatele studiului nostru nu identifică nici o corelație între polimorfismul Ile105Val al genei GSTP1, polipoza nazală şi hiposmie.

Cuvinte cheie: GST, polimorfism, polipoză nazală, hiposmie

Received: $4^{\text {h }}$ February 2013; Accepted: $13^{\text {th }}$ April 2013; Published: $15^{\text {th }}$ June 2013.

\section{Introduction}

Glutathione S-transferases (GSTs) are biological compounds with functions involved in phase II detoxification processes, inflammation, cell proliferation, oxidative stress response, carcinogenesis and tumor progression and drug resistance (1-3). GSTs isoenzymes are divided in four major classes: $\alpha, \theta, \mu$ and $\pi$ (4) and were demonstrated to have an important role in inflammatory diseases and cancer (5-7).

The lack of GSTs activity could be the result of inherited non-functional null alleles for these genes (8-10). The studies showed that approximately $50 \%$ of the Caucasian individuals could be homozygous for GSTM1 null alleles, 15-30\% are homozygous for GSTT1 null alleles and $15-20 \%$ are positive for Ile105Val GSTP1 polymorphism (11-13).

It has been showed that the olfactory epithelium exposed to the xenobiotic compounds such as odorants, airborne and environmental polluting toxic chemicals (cigarette smoke), presents a high concentration of biotransformation enzymes, therefore GSTs could play an important role in detoxification processes in this tissue (14). According recent studies, GSTs has an increased activity in rat olfactory epithelium, 5-7 times higher than in other airway tissues, suggesting an important role of these enzymes in chemoreception and sensory cell protection against chemical compounds (14).

\section{Aims}

The aim of our study was to assess the possible relation between null genotypes for the GSTM1/GSTT1 and Ile105Val GSTP1 polymorphism in normosmic subjects and hyposmic nasal polyposis patients. 


\section{Patients and methods}

The study was designed as a case control study and comprised a group of randomly selected 75 patients with nasal polyposis (NP) all with hyposmia and 125 normosmic controls were recruited from cases admitted and investigated in the Ear, Nose and Throat (ENT) Department of the Emergency County Hospital ClujNapoca. All cases and controls received extensive anamnesis, general physical examination, routine biochemical blood count analysis and a complete ENT evaluation. Nasal polyposis was confirmed by anterior rhinoscopy, nasal endoscopy and sinus computerized tomography (CT). For a detailed analysis of the studied polymorphisms among patients, the study group was split in two subgroups: "de novo" polyposis and recurrent nasal polyposis associated with hyposmia. Subjective hyposmia was evaluated in a bilateral mode using the "Sniffin' Sticks" test package (Burghardt, Wedel, Germany) (15) in all patients with nasal polyposis. The "Sniffin' Sticks" test battery included specific tests for odor threshold, odor discrimination and odor identification with Romanian cross-cultural adaptation $(16,17)$.

After the initial evaluation, allergy assessment was performed in all patients using specific serologic and skin prick tests, and patients with asthma received special evaluation in the Pneumology Department.

For the specific genetic investigation a sample of $2 \mathrm{ml}$ of venous blood was collected on EDTA from all patients and controls. DNA extraction and purification was performed using a commercial DNA Purification Kit (Wizard ${ }^{\circledR}$ Genomic DNA Purification Kit, Promega, MA, USA).

The study was approved by the Ethics Committee of the „Iuliu Hatieganu” University of Medicine and Pharmacy of Cluj Napoca, and all participants were provided a written informed consent.

\section{GSTM1 and GSTT1 genotyping}

GSTM1 and GSTT1 allele genotyping was carried out by using a multiplex PCR protocol
(18). Briefly, the amplification was made in a total volume of $25 \mu \mathrm{l}$ reaction mixture containing 12.5 $\mu \mathrm{l}$ 2xPCR Master Mix (Thermo Fischer Scientific Inc., MA, USA), 10 pmoles of each forward and reverse specific primers and free nucleases water to $25 \mu \mathrm{l}$. For GSTM1 and GSTT1 null allele identification we used 3 pairs of primers (Eurogentec, Belgium) and therefore we obtained 3 different amplified fragments, one of $215 \mathrm{bp}$ (for GSTM1), one of $480 \mathrm{bp}$ (for GSTT1) and a $268 \mathrm{bp}$ fragment (for the amplification of a $\beta$ Globin gene control fragment). Termocycling conditions consisted of denaturation at $94^{\circ} \mathrm{C}$ for 5 minutes and then 35 repetitive cycles of initial denaturation at $94^{\circ} \mathrm{C}$ of 1 minute each, primers annealing for 1 minute at $58^{\circ} \mathrm{C}$, elongation at $72^{\circ} \mathrm{C}$ for 1 minute and then a 10 minute final polymerization at $72^{\circ} \mathrm{C}$. (Mastercycler Gradient ${ }^{\circledR}$, Eppendorf, Germany).

The resulted amplification products were then analyzed by agarose $2 \%$ gel electrophoresis (MetaPhor ${ }^{\circledR}$ Agarose, Cambrex Bio Science Inc.). The absence of the amplification specific products demonstrated the presence of the null genotypes. This protocol easily identifies the GSTT1 and GSTM1 homozygous null genotypes but cannot distinguish between homozygous and heterozygous positive state for GSTT1 and GSTM1 genes.

\section{GSTP1 genotyping}

The GSTP1 Ile105Val gene variant was analyzed using a PCR-RFLP method as described (18). DNA was amplified in a mixture containing the same reagents as previously described for GSTM1 and GSTT1 amplification. Amplification was carried out in the following conditions: 5 minute of an initial denaturation at $95^{\circ} \mathrm{C}$ and 30 cycles of denaturation at $94^{\circ} \mathrm{C}$ for 30 seconds, annealing at $55^{\circ} \mathrm{C}$ for 30 seconds and elongation at $72^{\circ} \mathrm{C}$ for 30 seconds than a final polymerization for 5 minute at $72^{\circ} \mathrm{C}$.

The amplification products were digested overnight with 5 units of BsmAI enzyme (Thermo Fischer Scientific Inc., MA, USA) and the resulting DNA fragments then separated on a $3 \%$ agarose gel (MetaPhor ${ }^{\circledR}$ Agarose, Cambrex Bio 


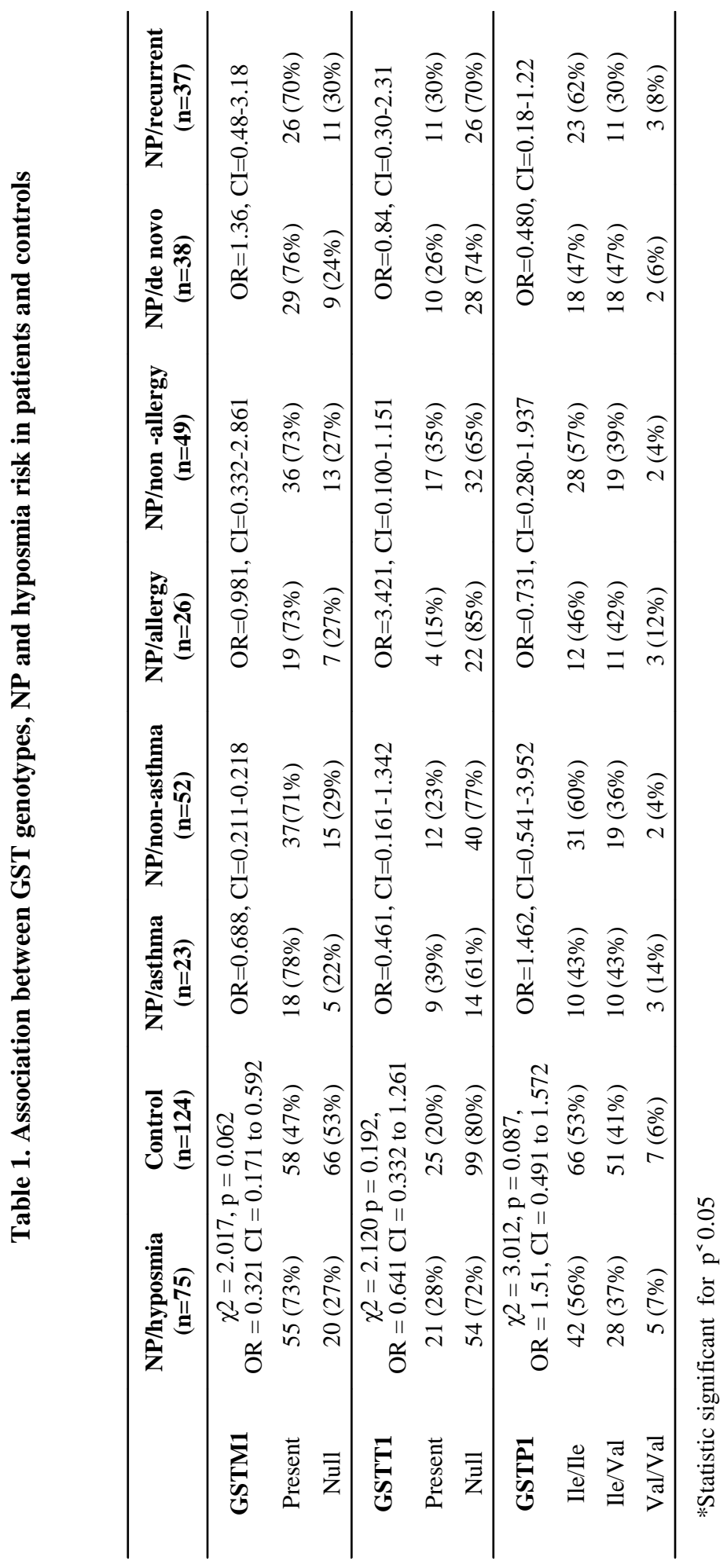


Table 2. Nasal Polyposis associated hyposmia risk evaluation for GSTP1 gene, Ile105Val polymorphism Fisher Test (Dominant model - Ile/Val+Val/Val vs. Ile/Ile)

\begin{tabular}{lccccc}
\hline Genotype & \multirow{2}{*}{$\chi^{2}$} & $\mathbf{p}$ & Odd ratios & \multicolumn{2}{c}{ 95\% CI } \\
\cline { 5 - 6 } & & & Inferior limit & Superior limit \\
\hline GSTP1 Ile ${ }^{105} \mathrm{Val}$ & 0.032 & 0.523 & 1.645 & 1.000 & 2.876 \\
\hline Fisher Test $($ Recessive model & Val/Val vs. Ile/Val + Ile/Ile) & & & \\
\hline Genotype & $\chi^{2}$ & $\mathbf{P}$ & Odd ratios & Inferior limit & Superior limit \\
\hline GSTP1 Ile ${ }^{105} \mathrm{Val}$ & 0.028 & 0.723 & 0.784 & 0.512 & 1.651 \\
\hline
\end{tabular}

Table 3. Association between GSTM1/GSTT1 double - null genotypes, NP and hyposmia risk in patients and controls

\begin{tabular}{ccccc}
\hline \multirow{2}{*}{ Study group } & \multirow{2}{*}{ odd ratios } & 95\% CI & 90rior limit & Superior limit \\
\hline Patients/control & & & Inferion & 9.543 \\
De novo/recurrent NP & $0.015^{*}$ & 4.035 & 1.706 & 2.190 \\
Asthma/no asthma NP & 0.406 & 0.778 & 0.277 & 1.867 \\
Allergic/non allergic NP & $0.027^{*}$ & 3.455 & 0.213 & 10.406 \\
\hline
\end{tabular}

*Statistic significant for $\mathrm{p}^{<} 0.05$.

Science Inc.) . The homozygous Ile/Ile genotype is corresponding to undigested $176 \mathrm{bp}$ fragment. The complete digestion of the amplified product results in two fragments of 91 and $85 \mathrm{bp}$ and defines the presence of the homozygous $\mathrm{Val} / \mathrm{Val}$ genotype, while the presence of all three fragments (176, 91 and 85 bp), highlights the presence of the Ile/Val heterozygous genotype.

\section{Statistical analysis}

For statistical analysis we used the SPSS 18.0 for Windows software (SPSS, Inc, Chicago, Il., USA).

Odds ratio (OR) assessment with $95 \%$ confidence limits were calculated by logistic regression for proper statistical analysis. GSTM1 and GSTT1 genotypes were classified as homozygous deletion (null alleles) or not deleted. $\mathrm{P}$ value was also calculated for a more accurate risk evaluation. Ile $105 \mathrm{Val}$ variant of GSTP1 gene statistical assessment was also evaluated by logistic regression and quantified by odds ratio (OR) with $95 \%$ confidence limits and fol- lowed by comparative analysis according to dominant and recessive models.

\section{Results}

Statistical analysis did not reveal an increased frequency for GSTM1 and GSTT1 null genotypes in the study group compared to controls. $(\mathrm{GSTM} 1 \chi 2=2.017, \mathrm{p}=0.062, \mathrm{OR}=0.321$ $\mathrm{CI}=0.171$ to 0.592 , GSTT1 $\chi 2=2.120 \mathrm{p}=0.192$, $\mathrm{OR}=0.641 \mathrm{CI}=0.332$ to 1.261 ). Also, comparative analysis for Ile105Val variant of GSTP1 gene revealed no statistical differences between patients and controls $(\chi 2=3.012, \mathrm{p}=0.087, \mathrm{OR}=$ $1.514, \mathrm{CI}=0.491$ to 1.572 ) (Table 1). Molecular analysis of GSTP1 Ile105Val using the Fisher test by autosomal recessive model (variant homozygous genotype vs. heterozygous and common homozygous genotype) and autosomal dominant model (variant homozygous genotype and heterozygous vs. common homozygous genotype) reveals no statistically significant differences 
between patients group compared to the control group $(\chi 2=0.028, \mathrm{OR}=0.784, \mathrm{CI}=0.512-1.651$, $\mathrm{p}=0.723 ; \chi 2=0.032, \mathrm{OR}=1.645, \mathrm{CI}=1-2.876, \mathrm{p}=$ $0.523)$ (Table 2).

No statistical differences were found between de novo nasal polyposis hyposmic patients and recurrent nasal polyposis hyposmic patients for GSTT1/GSTM1 null genotypes (GSTM1 OR=1.36, $\mathrm{p}=0.554, \mathrm{CI}=0.48-3.18, \mathrm{GSTT} 1$ $\mathrm{OR}=0.84, \mathrm{p}=0.742, \mathrm{CI}=0.30-2.31$ and Ile105Val GSTP1, OR=0.480, $\mathrm{p}=0.124, \mathrm{CI}=0.18-1.22$ ).

There were no statistical significant differences between asthma diagnosed patients when compared to non-asthmatic patients regarding the GSTT1/GSTM1 null genotypes (GSTM1, OR $=0.680, \mathrm{p}=0.522, \mathrm{CI}=0.215$ 2.182, GSTT1, OR=0.466, $\mathrm{p}=0.157$, $\mathrm{CI}=0.162-1.343)$ and Ile105Val GSTP1 with $\mathrm{OR}=1.466, \mathrm{p}=0.448, \mathrm{CI}=0.544-3.943$ ).

The same non-significant differences were highlighted allergic and non-allergic individuals (GSTM1, OR=0.980, $\mathrm{p}=0.970$, $\mathrm{CI}=0.334-2.868$; GSTT1, OR $=0.342, \mathrm{p}=0.084$, $\mathrm{CI}=0.101-1.155$ and Ile105Val GSTP1 with $\mathrm{OR}=0.738, \mathrm{p}=0.537, \mathrm{CI}=0.282-1.932)$.

When combined GSTM1 and GSTT1 null genotype (double-null genotype) was compared between patients and controls, significant statistical differences were found $(\mathrm{p}=0.0015$, $\mathrm{OR}=4.0351 ; \mathrm{CI}=1.706-9.543)$. Statistical analysis for combined GSTM1/GSTT1 null genotypes for de novo/recurrent polyposis and respectively asthmatic/non-asthmatic patients revealed no statistical significant differences $(\mathrm{p}=0.635, \mathrm{OR}=0.778$, $\mathrm{CI}=0.277-2.190 ; \mathrm{p}=0.406$, OR=0.631, $\mathrm{CI}=0.213$ 1.867). Although, statistical differences were highlighted when allergic NP patients were compared to non-allergic NP patients $(\mathrm{p}=0.027$, $\mathrm{OR}=3.455, \mathrm{CI}=1.147-10.406$ ) (Table 3).

\section{Discussions}

GSTs are an important family of enzymes involved in detoxification of several xenobiotics, so this mechanism protects tissues from the harm- ful effects of oxidative stress, and therefore against chemically induced tissue damage $(5,11,18)$. Nasal polyposis and associated hyposmia are considered to be multifactorial disorders (19); multiple factors could be involved in the etiophatogeny of these two related conditions. Although scientific studies demonstrated that individuals with nasal polyposis associate low levels of blood and therefore decreased mucosal tissue antioxidants levels (20), there is no valid data to prove that GSTs are involved in nasal polyposis and hyposmia development. According to statistical analysis our study revealed that there are no significant differences between hyposmic patients with nasal polyposis and controls for GSTM1 and GSTT1 null alleles and Ile105Val GSTP1 polymorphism. Our results are in agreement with another study evaluating the same genetic variants (11). Although comparative analysis did not reveal statistical differences between patient group and controls, GSTM1 null genotypes were more frequents in hyposmic patients with nasal polyposis than in controls. Scientific studies showed that GSTP1 gene polymorphism could influence on the one hand the metabolic activation and also the detoxification of xenobiotics and is therefore, a link between the gene variants and individual susceptibility to different inflammatory disorders $(21,22)$ but only few studies investigated the relationship between Ile105Val GSTP1 polymorphism, nasal polyposis and hyposmia. The results of our study show no correlation between this genetic variant, nasal polyposis and hyposmia, in agreement with one of the few published researches on this subject (23).

Comparative analysis of GSTM1/GSTT1 null alleles and Ile105Val GSTP1 polymorphism among patients with "de novo" polyposis and recurrent nasal polyposis associated with hyposmia, revealed no statistical differences between these two groups.

Recent studies demonstrated that polymorphism of GST genes are associated with asthma $(5,24,25)$ although other studies could not establish an association between these genetic variants and patients with nasal polyposis 
and asthma $(26,27)$. We evaluated the distribution of GSTT1/GSTM1 null alleles and Ile105Val GSTP1 in patients with nasal polyposis and associated allergy or asthma compared to non-allergic patients. There were no statistical significant differences in genotypes distribution between allergic and non-allergic subjects; the same results were highlighted for genetic variants above when compared asthma diagnosed patients to non-asthmatic patients.

An important finding for our study is that patients presenting both GSTM1 and GSTT1 null genotypes (double null genotypes) are more likely predisposed to develop nasal polyposis and hyposmia when compared to controls. Statistical analysis for combined GSTM1/GSTT1 null genotypes for allergic NP patients compared to non-allergic NP patients revealed significant differences; therefore according the results of our study, combined GSTM1/GSTT1 null genotypes could be considered risk factors for NP and hyposmia development in allergic individuals.

Nasal polyposis (NP) is a complex disease with a pathophysiology that is likely to be influenced by multiple environmental and genetic factors (28). Although several studies proved that some genetic polymorphisms (SNPs) are likely to influence the occurrence of NP (29) and hyposmia, no single gene or genetic variant has been shown to be uniquely related to nasal polyposis and hyposmia (30), therefore future studies are needed to identify key genes and control mechanisms involved in NP and hyposmia etiopathogenesis.

\section{Acknowledgements}

This work was funded by the POSDRU/88/1.5/S/58965 Human Resources Operational International Development Project, co-financed by the European Social Found 2007 - 2013.

Conflict of interest . None to declare.

\section{Abreviation list}

ENT - ear, nose, throat

GST - Glutathione S transferase

GSTM1- Glutathione S transferare Mi 1

GSTT1 - Glutathione S Transferase T1

GSTP1 - Glutathione S transferase Pi 1

NP - Nasal Polyposis

Ile - Isoleucine

Val - Valine

PCR - Polymerase Chain Reaction

RFLP - Restriction Fragment Length Polymorphism

\section{References}

1. Hayes JD, Strange RC. Glutathione S-transferase polymorphisms and their biological consequences. Pharmacology 2000. 61(3):154-66.

2. Nebert DV, Vasiliou V. Analysis of the glutathione Stransferase (GST) gene family. Human Genomics 2004;1:460-464.

3. Hayes JD, Pulford DJ. The Glutathione S Transferase supergene family regulation of GST and the contribution of the isoenzymes to cancer chemoprotection and drug resistance. Crit. rev Biochem Mol. Biol 1995;30:445-600.

4. Ketterer B, Christodoulides LG. Enzymology of cytosolic glutathione S-transferases. Adv.Pharmacol 1994;27:37-69.

5. Tamer L, Calıkoglu M, AteS NA, Yıldırım H, Ercan B , Saritas E et al. Glutathione-S-Transferase gene polymorphisms (GSTT1, GSTM1, GSTP1) as increased risk factors for asthma. Respirology 2004;9:493-498.

6. Tamer L, Ercan B, Camsarı A, Yıldırım H, Cicek D, Sucu N et al. Glutathione-S-transferase gene polymorphism as a susceptibility factor in smoking related coronary artery disease. Basic Res Cardiol 2004;99:223-229.

7. Mcllwain CC, Townsend DM, Tew KD. Glutathione S-transferase polymorphisms: cancer incidence and therapy. Oncogene 2006;25(11):1639-48.

8. Watson MA, Stewart RK, Smith GB, Massey TE, Bell DA. Human glutathione-S-transferase P1 polymorphisms: relationship to lung tissue enzyme activity and population frequency distribution. Carcinogenesis 1998;19:275-280. 9. Seidegard J, Vorachek WR, Pero RW. Hereditary differences in the expression of the human Glutathione transferase active on trans-stilbene oxide are due to a gene deletion. Proc Natl Acad Sci USA 1988;85:7293-7297.

10. Rebbeck TR. Molecular epidemiology of the human glutathione S-transferase genotypes GSTM1 and GSTT1 in cancer susceptibility. Cancer Epidemiol. Biomarkers Prev. 1997 Sep;6(9):733-43.

11. Arbaq H, Cora T, Acar H, Ozturk K, Sari F, Ulusoy B. Lack of association between the glutathione-S-transferase genes (GSTT1 and GSTM1) and nasal polyposis. 
Rhinology 2006; 44:14-18.

12. Dali AK. Molecular basis of polymorphic drug metabolism. J Mol.Med, 1995, 73:539-553.

13. Zuntar I, Kalanj-Bognar S, Popic E, Petlevki R, Stefanocic M, Demarin V. The glutathione S-transferase polymorphisms in a control population and in Alzheimer's disease patients. Clin Chem Lab Med 2004;42(3):334-9.

14. Ben-Arie N, Khen M, Lancet D. Glutathione S-transferases in rat olfactory epithelium: purification, molecular properties and odorant biotransformation. Biochem $\mathrm{J}$. 1993 Jun 1;292(Pt 2):379-84.

15. Hummel T, Sekinger B, Wolf SR, Pauli E, Kobal G. 'Sniffin'sticks': olfactory performance assessed by the combined testing of odor identification, odor discrimination and olfactory threshold. Chem Senses. 1997;22:39-52. 16. Kobal G, Klimek L, Wolfensberger M, Gudziol H, Temmel A, Owen CM, Seeber H, Pauli E, Hummel T. Multicenter investigation of 1036 subjects using a standardized method for the assessment of olfactory function combining tests of odor identification, odor discrimination, and olfactory thresholds. Eur Arch Otorhinolaryngol. 2000;257: 205-211.

17. Catana I, Negoias S, Maniu A, Porojan M, Cosgarea M. A modified version of "Sniffin'Sticks" odor identification test: The Romanian cultural adaptation. Clujul Medical 2012;85;2:218-223.

18. Dogru H, Delibas N, Doner F, Tuz M. Free radical damage in nasal polyp tissue. Otolaryngol Head Neck Surg 2001;124:570-572.

19. Fokkens W, Lund V, Mullol J. European position paper on rhinosinusitis and nasal polyps. Rhinol Suppl. 2007:1-136.

20. Dagli M, Erylmaz A, Besler T, Akmansu H, Acar A, Korkmaz H. Role of free radicals and antioxidants in nasal polyps. Laryngoscope 2004;114:1200-1203.

21. Ruwali M, Singh M, Pant MC, Parmar D. Polymorphism in glutathione S-transferases: susceptibility and treatment outcome for head and neck cancer. Xenobiotica. 2011;1122-1130.

22. Jourenkova-Mironova N, Voho A, Bouchardy C,
Wikman H, Dayer P, Benhamou S, et al. Glutathione Stransferase GSTM3 and GSTP1 genotypes and larynx cancer risk. Cancer Epidemiol. Biomarkers Prev. 1999 Feb;8(2):185-8.

23. Ozcan C, Tamer L, Ates NA, Görür K. The glutathione-S-transferase gene polymorphisms (Gstt1, Gstm1, and Gstp1) in patients with non-allergic nasal polyposis. Eur Arch Otorhinolaryngol. 2010;267:227-32.

24. Hanene C, Jihene L, Jamel A, Kamel H, Agnes H. Association of GST genes polymorphisms with asthma in Tunusian children. Mediators Inflamm. 2007;10;1155.19564, DOI: 10.1155/2007/19564

25. Brutsche M, Schindler C, Downs SH, Gerbase MW, Berger W, Probst-Hensch NM SAPALDIA Team Glutathione-Stransferase genotype increases risk of progression from bronchial hyperresponsiveness to asthma in adults. Thorax 2008;63:322-328.

26. Imboden M, Rochat T, Holla LI, Stejskalova A, Vasku A. Polymorphism of the GSTM1 and GST1 genes in patients with allergic diseases in the Czech population. Allergy 2006;61:265-267.

27. Carrol WD, Lenney PW, Jones PW, Strange RC, Child F, Whyte MK, Primhak RA, Fryer AA, Effects of glutathione-stransferase M1, T1 and P1 on lung function in asthmatic families. Clin Exp Allergy 2005;35:11551161.

28. Figueiredo CR, Santos RP, Silva ID, Weckx LL. Microarray cDNA to identify inflammatory genes in nasal polyposis. American journal of rhinology. 2007 MarApr;21(2):231-5.

29. Erbek SS, Yurtcu E, Erbek S, Atac FB, Sahin FI, Cakmak O. Proinflammatory cytokine single nucleotide polymorphisms in nasal polyposis. Archives of otolaryngology-- head \& neck surgery. 2007 Jul;133(7):705- 9.

30. Anand VK, Kacker A, Orjuela AF, Huang C, Manarey $\mathrm{C}$, Xiang $\mathrm{J}$. Inflammatory pathway gene expression in chronic rhinosinusitis. American Journal of rhinology. 2006 Jul-Aug;20(4):471-6. 